\title{
PERSEPSI ORANG TUA DAN GURU MENGENAI BAHASA INGGRIS PADA ANAK USIA DINI DI TK ABA KARANGMALANG YOGYAKARTA
}

Dikirim tanggal 20 September 2017 Diterima tanggal 26 Desember 2017 Dipublish tanggal 27 Desember 2017

Faqihatuddiniyah, Harun Rasyid

Prodi PAUD Program Pascasarjana Universitas Negeri Yogyakarta

Email: Faqihatuddiniyahnia@gmail.com, harun_pgpauduny@yahoo.com

\begin{abstract}
The aims of this study is to find out the perception of parents' and teacher's about the importance of English for early childhood. This research was a qualitative study, the descriptive approach using FGD. It was conducted in TK ABA Karangmalang. The result of analysis in this research shows that mostly parents and teachers state that English for early childhood is important, learning English in early ages is better for children's memory and brain development, children have a high curiosity which is suitable to teach them English or other languages, and it is also related to their golden age development. English factor in children has a positive influence that can enhance child language acquisition in children's language development, while English factor in children also has a negative impact as the low ability of the child's first language.
\end{abstract}

Keywords: parents' perception, teacher's perception, English for early childhood

\begin{abstract}
ABSTRAK
Tesis ini bertujuan untuk mengetahui persepsi orang tua dan guru mengenai pentingnya bahasa Inggris untuk anak usia dini. Penelitian ini merupakan penelitian kualitatif dengan pendekatan deskriptif kualitatif melalui FGD yang dilaksanakan di TK ABA Karangmalang Yogyakarta. Hasil penelitian ini menunjukkan bahwa sebagian besar orang tua dan guru menjawab bahwa pentingnya bahasa Inggris pada anak usia dini, semakin dini anak-anak diajarkan semakin baik untuk ingatan dan pembentukan otak mereka, anak-anak memiliki rasa ingin tahu yang tinggi akan lebih bermanfaat jika diisi dengan pembelajaran bahasa Inggris dan bahasa lainnya, ini juga berkaitan dengan masa emas perkembangan anak. Faktor bahasa Inggris pada anak adalah membawa pengaruh positif yang mampu meningkatkan pemerolehan bahasa anak pada perkembangan bahasa anak, sedangkan faktor bahasa Inggris pada anak juga membawa pengaruh negatif yaitu rendahnya kemampuan anak tentang bahasa pertama.
\end{abstract}

Kata Kunci: persepsi orang tua, persepsi guru, bahasa Inggris pada anak usia dini

\section{Pendahuluan}

Bahasa Inggris merupakan suatu bahasa yang sangat penting dalam dunia internasional terutama di era globalisasi seperti sekarang ini. Bahasa Inggris digunakan untuk berkomunikasi dengan orang lain diberbagai negara. Dengan menguasai bahasa Inggris, orang akan bisa masuk dan mengakses dunia informasi teknologi dengan mudah. Dengan pengenalan bahasa Inggris sejak dini di Taman kanak-kanak maka anak akan mengenal dan mengetahui bahasa Inggris lebih awal. Sehingg, mereka akan mempunyai pengetahuan dasar yang lebih baik sebelum melanjutkan tingkat pendidikan yang lebih tinggi. Guru dapat memberikan bekal bagi anak bahwa dengan menguasai bahasa Inggris maka bisa memberikan kesempatan yang lebih terbuka untuk mengembangkan diri guna memperoleh kesempatan yang lebih baik menghadapi persaingan lapangan kerja dan karir di masa yang akan datang. Bahasa Inggris telah menjadi suatu alat yang sangat menentukan bagi kelanjutan pendidikan, pekerjaan serta status sosial masyarakat. 
Orangtua yang ingin anak mereka berkembang secara linguistik dalam mengusai beberapa bahasa tidak hanya disambut dengan baik oleh anak-anak mereka, tapi juga oleh negara ini, dengan tulus.

Keluarga sebagai institusi pendidikan yang utama dan pertama semakin sulit dalam menjalankan fungsinya. Peran keluarga (orangtua) tidak saja menjadi lebih berat, tetapi juga kompleks. Kondisi intensitas hubungan orangtua dengan anak tidak ditentukan oleh kualitas komunikasi yang berhasil dibangun, yaitu komunikasi interpersonal antara orangtua dengan anak. Pendidikan anak usia dini sebagai gerbang pertama pendidikan diharapkan mampu meletakkan dasar-dasar yang kokoh sebagai persiapan pendidikan dan kehidupan selanjutnya. Dalam hal ini keluarga mempunyai peran sangat penting dan strategis dalm proses pendidikan anak.

Persepsi Orang tua dan Guru, Bahasa Inggris

Manusia sejak diciptakan dan dilahirkan lebih sempurna dibandingkan dengan makhluk ciptaan lainnya, perbedaan itu tidak hanya dari penampilan fisiknya saja (jasmani) tetapi manusia dibekali dengan akal perasaan dan panca indra. Dengan potensi itulah manusia dapat menangkap rangsangan dan mengenal dunia luar seehingga mampu mengenali dirinya sendiri dan menilai stimulus yang ditangkapnya dan melakukan penyesuaian terhadap keadaan sekitarnya yang mana hal ini berkaitan dengan persepsi.

Bahasa adalah bentuk komunikasi yang dilakukan baik spontan, tertulis atau berupa isyarat, yang didasarkan pada suatu sistem dari simbol. Bahasa terdiri dari semua kata yang digunakan oleh suatu komunitas dan semua aturan untuk mengubah atau menggabungkan kata-kata tersebut. Bahasa Inggris (English) merupakan bahasa resmi dari banyak negara-negara persemakmuran dan dipahami serta dipergunakan secara meluas. Bahasa Inggris dipergunakan di lebih banyak negara di dunia dibanding bahasa yang lain serta dibanding bahasa yang lain kecuali bahasa Cina, bahasa ini juga dipergunakan oleh lebih banyak orang. Bahasa Inggris sebagai salah satu bahasa internasional memainkan peranan yang penting untuk berkomunikasi dengan dunia luar khususnya dalam menyerap ilmu pengetahuan dan teknologi. Salah satu aspek yang perlu dikuasai oleh anak adalah kemampuan berbahasa Inggris yang baik, baik lisan maupun tertulis. Kemampuan bahasa Inggris yang baik harus menguasai keempat keterampilan bahasa dan kosa kata serta tata bahasa.

Senada dengan itu, Erik seorang ahli neurologi mengungkapkan sebelum masa pubertas, daya pikir anak lebih lentur. Maka dari itu anak lebih mudah belajar bahasa, sedangkan sesudahnya akan semakin berkurang dengan pencapaian tidak maksimal. Bahasa Inggris merupakan bahasa internasional yang dimana pada saat ini pengenalan pembelajaran bahasa Inggris sudah dimulai di TK. Pengenalan bahasa Inggris di TK berupa kosakata-kosakata mengenai hal-hal yang terdekat dengan anak, hal ini bertujuan untuk lebih memudahkan anak untuk mengingatnya. Selain itu, dalam mengajarkan kosakata pada anak dapat menggunakan berbagai cara yang dapat menarik perhatian anak melalui media, permainan, maupun metode pembelajaran yang menarik dengan hal ini diharapkan anak dapat tertarik pada kegiatan pembelajaran yang berlangsung.

Kemampuan anak untuk mengetahui dan menguasai bahasa Inggris menjadi kebutuhan untuk kemajuan ilmu pengetahuan dan teknologi yang begitu pesat.Peranan bahasa Inggris sebagai bahasa kedua di Indonesia berfungsi sebagai alat untuk membantu persaingan dan kerjasama ditataran global baik itu melalui pendidikan, perdagangan, pemanfaatan sains dan teknologi serta kegiatan interakssi manusia lainnya. 
Peran aktif orang tua sangat diperlukan dalam hal ini, dengan kata lain orang tua pun dituntut untuk mengetahui sedikit tentang bahasa Inggris agar mereka bisa membeli buku tentang dasar bahasa Inggris dan mengajarkannya pada anak-anak mereka di rumah. Orang tua yang memberikan kehangatan, kenyamanan, cinta dan kasih sayang pada anak sejak usia dini, akan memungkinkan anak mengembangkan rasa percaya pada lingkungannya. Bila tahap-tahap ini dilalui dengan baik, anak akan lebih mudah mengembangkan percaya diri dan inisiatif pada dirinya. Dengan kata lain anak tidak akan di dominasi oleh rasa ragu ataupun cemas dalam mengeksploitasi lingkungannya.

Pendidikan anak pada dasarnya adalah tanggung jawab orang tua. Hanya karena keterbatasan kemampuan orang tua, maka perlu adanya bantuan dari orang-orang yang mampu dan mau membantu orang tua dalam pendidikan anak-anaknya, terutama dalam mengajarkan berbagai ilmu dan keterampilan yang selalu berkembang. Orang-orang yang mampu dan mau yang bekerja di sekolah, ini yang sering disebut guru. Oleh karena itu para siswa memandang gurunya sebagai ganti orang tuanya, memandang gurunya seperti memandang orang tuanya, cenderung mempunyai perasaan terhadap guru seperti perasaanya terhadap orang tuanya. (Zakiah Daradjat, 1994, p.17)

Dalam pembelajaran bahasa, baik bahasa pertama, kedua, atau bahasa asing pengajaran komponen bahasa merupakan bagian dari program bahasa. Meskipun mengajar praktis dilapangan berlangsung, secara terpadu, guru dan calon guru perlu memahami beberapa konsep penting yang berkaitan dengan ketiga komponen bahasa terutama yang mengenai komponen bahasa inggris.

Pada umumnya komponen bahasa terdiri dari tiga, yaitu grammar (tata bahasa), vocabulary (kosa kata), dan pronunciation (pelafalan).

1. Tata bahasa atau kaidah-kaidah bahasa merupakan pola dan aturan yang harus diikuti bila kita mau belajar suatu bahasa dengan benar.

2. Kosa kata atau vocabulary merupakan kumpulan kata yang dimiliki oleh suatu bahasa dan memberikan makna bila kita menggunakan bahasa tersebut.

3. Pelafalan atau pronunciation adalah cara mengucapkan kata-kata suatu bahasa.

Pentingnya Pendidikan Bahasa Inggris Pada Anak Usia Dini

Banyak orang tua yang ingin mengajarkan anaknya belajar bahasa Inggris sejak usia dini, memang tidak mudah untuk mengajarkan anak usia dini, bukan hanya bahasa Inggris saja akan tetapi hal-hal yang lainnya. Dalam mengajarkan bahasa Inggris pada anak usia dini tentu mempunyai cara yang sangat berbeda jika dibandingkan dengan remaja atau dewasa. Pada anak usia dini, pengajaran bahasa Inggris hanyalah sebatas pengenalan. Jadi, anak usia dini hanya bisa diajarkan dasardasarnya saja dan mereka diajarkan dengan cara bermain, akan tetapi bukan hanya sekedar bermain. Bermain di sini adalah bermain yang diarahkan. Dengan cara inilah mereka bisa mengetahui banyak hal. Perlu kita ketahui bahwa pada saat anak bermain keadaan otak anak sedang tenang karena ia merasa senang dan ceria. Dengan keadaan seperti ini ilmu yang kita ajarkan bisa masuk dan tertanam dengan baik dan mudah dalam otak mereka.

Pernyataan tersebut didukung oleh banyak ahli yang menyatakan bahwa sangat baik bagi seorang anak untuk belajar bahasa keduanya sebelum ia berusia 10 tahun, artinya kemampuan belajar bahasa kedua anak akan lebih baik jika dia belajar sebelum usia 10 tahun. Maka dari itu, bahasa Inggris sebaiknya dikenalkan sejak dini, karena pada usia dini merupakan masa keemasan dimana segala sesuatu dapat diserap dengan mudah dan cepat. 
Pembelajaran bahasa Inggris pada anak usia dini hanya sebatas pengenalan dan dasardasarnya saja. Jadi, kita sebagai pendidik mengajarkan mereka hal-hal yang sangat dasar dahulu, misalnya huruf-huruf abjad bahasa Inggris, angka, macam-macam buah-buahan, macam-macam hewan, macam-macam warna, dan sedikit percakapan yang simple dan mudah (seperti good morning, how are you, dll). Peran aktif orang tua sangat diperlukan dalam hal ini, dengan kata lain orang tua pun dituntut untuk mengetahui sedikit tentang bahasa Inggris agar mereka bisa membeli buku tentang dasar bahasa Inggris dan mengajarkannya pada anak-anak mereka di rumah.

To extent does English language teacher education curriculum prepare prospective teachers for teaching young learners (Hasan Özkan, 2010, p.18). Dengan perubahan terbaru dalam sistem pendidikan Turki, murid kelas empat yang diperkenalkan ke bahasa Inggris dalam kurikulum sekolah dasar mereka.Perubahan tersebut mengakibatkan pertumbuhan pentingnya praktik pendidikan guru dalam kaitannya dengan pengajaran bahasa Inggris untuk pelajar muda.

Teachers' Beliefs in Teaching English for Kids at a Kindergarten: A Case Study of Studentsfrom the Department of Applied English (Yu-wei Chu, 2014, p.101). Keyakinan guru termasuk empat aspek dalam hal pengajaran bahasa Inggris, gurumurid interaksi di kelas, perencanaan kurikulum dan pembelajaran bahasa Inggris.

Teaching Young Learners to Efficiently Communication in English (Adrian Brunello, 2013, p.123). Pelajar muda harus bersenang-senang dengan bahasa Inggris! memperkenalkan kepada pelajar untuk teori dan praktek mengajar pelajar muda di kelas EFL. Mereka akan terlibat dalam kegiatan menyenangkan yang dirancang khusus untuk pelajar muda, seperti lagu, nyanyian, drama jari, dan bercerita. Selain itu, peserta akan membahas pendekatan untuk bahasa pengajaran dalam konteks yang bermakna dan berbagi teknik yang efektif untuk membuat masukan bahasa partisipasi siswa dipahami dan mendorong.

Which is the Most Appropriate Strategy for Very Young Language Learners (Suhendan Er, 2014, p.829). Hasil menunjukkan bahwa dibandingkan dengan ajaran yang kurang menarik, instruksi yang menyenangkan ditemukan untuk menjadi lebih efektif dalam mengembangkan bahasa Inggris kesadaran sociopragmatik anak-anak dalam hal tugas-tugas yang melibatkan strategi permintaan sebagai lawan untuk membalas strategi. Hasil di atas menunjukkan bahwa, selain mengajar dengan menyenangkan, tindak tutur adalah variabel penting yang mempengaruhi bahasa kompetensi sociopragmatic kedua pada anak usia dini.

\section{Metode Penelitian}

Dalam penelitian kualitatif, pengumpulan data dilakukan melalui Focus Group Discussion (FGD), (Irwanto, 2006, pp.1-2) pada natural setting (kondisi yang alamiah), sumber data primer, dan teknik pengumpulan data lebih banyak pada observasi, wawancara mendalam (in depth interview) dan dokumentasi (Sugiyono, 2007, p.309). Tempat penelitian yang di pilih adalah TK ABA Karangmalang Yogya, Jalan Karangmalang, Yogyakarta. Sedangkan waktu penelitian disesuaikan jadwal sekolah yang bersangkutan pada semester 1 dengan cara diadakan pendekatan dengan key informan terlebih dahulu, menentukan informan, mengumpulkan data dan menganalisis data, dan terakhir menulis laporan penelitian. Model analisis yang digunakan dalam penelitian ini adalah model interactif yang dimulai dengan pengumpulan data, reduksi data, penyajian data, dan penarikan kesimpulan/verifikasi. Proses analisis data dilakukan secara terus menerus di dalam proses pengumpulan data selama penelitian berlangsung. 
Persepsi Orang tua Mengenai Bahasa Inggris Pada Anak Usia Dini

Pemahaman semua orangtua tentang pentingnya bahasa Inggris pada Anak Usia Dini adalah menurut orangtua penting sekali bahasa Inggris untuk anak usia dini karena bahasa Inggris saat ini menjadi bahasa Internasional yang di hampir semua negara sudah mempelajari bahasa Inggris ini, bahasa adalah komunikasi, bahasa adalah kunci segala-galanya sehingga tidak bisa dipungkiri lagi jika ingin anak-anak sukses anak-anak harus diajarkan/dikenalkan dengan bahasa sedini mungkin, bahasa Inggris juga adalah bahasa yang sangat wajib atau harus kita ketahui, kami para orangtua merasa sudah sangat terlambat untuk belajar bahasa sehingga kami tidak ingin anak-anak kami seperti kami, kami ingin pendidikan yang terbaik untuk anak-anak. Menurut para orangtua semakin dini anak-anak diajarkan semakin mudah bagi anak-anak menerima pelajaran, anak-anak akan sering mendengarkan bahasa Inggris semakin lama anak-anak akan semakin mengerti dan terbiasa dengan bahasa Inggris tersebut.

Menurut teori pembelajaran bahasa Inggris pada anak usia dini hanya sebatas pengenalan dan dasar-dasarnya saja. Jadi, kita sebagai pendidik mengajarkan mereka hal-hal yang sangat dasar dahulu, misalnya huruf-huruf abjad bahasa Inggris, angka, macam-macam buah-buahan, macammacam hewan, macam-macam warna, dan sedikit percakapan yang simple dan mudah (seperti good morning, how are you, dll). Peran aktif orang tua sangat diperlukan dalam hal ini, dengan kata lain orang tua pun dituntut untuk mengetahui sedikit tentang bahasa Inggris agar mereka bisa membeli buku tentang dasar bahasa Inggris dan mengajarkannya pada anak-anak mereka di rumah.

Jadi, menurut orang tua pentingnya bahasa Inggris pada anak usia dini sangat penting malah akan lebih baik menjadi pembelajaran bukan hanya sekedar pengenalan, menurut orang tua dan menurut teori memang bahasa Inggris sangat penting juga namun pada anak usia dini hanya sebatas pengenalan dan dasardasarnya saja.

Sikap orang tua mengenai bahasa Inggris untuk anak usia dini adalah kebanyakan dari mereka memang sangatlah setuju dengan adanya pembelajaran Bahasa Inggris untuk anak usia dini, sehingga kebanyakan orangtua memberikan sikap positif dengan adanya pelajaran tambahan atau ekstrakulikuler yang sudah ada di TK ABA Karangmalang ini. Karena menurut mereka zaman sekarang sudah tidak sama dengan zamannya mereka dulu, sehingga kami sebagai orang tua harus mengikuti zaman, yangmana sekarang ini bahasa Inggris adalah bahasa kedua di Indonesia, bahasa Inggris juga salah satu kunci komunikasi dunia saat ini, lihat saja media saat ini, elektronik dan lain-lain lebih menggunakan bahasa Inggris.

Peranan orang tua menurut (Jiyono, 1997, p.10) khususnya ibu akan sangat menentukan besarnya pengaruh proses pendidikan anak dilingkungan keluarga, dan yang pada akhirnya akan mempengaruhi prestasi belajar anak di sekolah. Peranan keluarga amat dominan dalam memberikan pendidikan usia dini sebelum anak masuk sekolah TK. Reese (Papalia, 2001, p.265) mengemukakan bahwa: The quality of mother-child conversation at ages 3-4 particularly about past events was a strong predictor of literacy skills prior to entering first grade. Most influental wa mother's use questions and comments that helped children elaborate on events or link them with other incidents. Children who took the lead in this conversations were more likely to be competent storytellers as kindergartners.

Jadi, menurut sikap orang tua yang saya lihat mengenai bahasa Inggris adalah sikap setuju dan positif, karena mereka memandang untuk masa depan anak-anak yang sudah berbeda dengan zaman mereka 
dulu. Begitu pula dengan teori yang saya lihat, menurut teori sikap atau peran orang tua sangatlah berpengaruh dalam proses pendidikan anak-anak, jadi jika pendapat mereka sudah setuju dan positif, sehingga apabila diselaraskan dengan teori yang sangat memegang bahwa orang tua sangat berpengaruh dalam proses pendidikan anak menurut saya ini sangatlah sesuai mengenai penerimaan orang tua dengan bahasa Inggris untuk Anak Usia Dini.

Pemahaman orangtua mengajarkan bahasa selain bahasa ibu pada anak dirumah. Menurut para orangtua pengajaran bahasa selain bahasa ibu itu dibiasakan dari kecil memang (Bahasa Indonesia) karena bahasa Indonesia memang juga sangat penting jika mereka hanya bisa bahasa Jawa nanti kami orangtua sendiri yang akan kerepotan mengajarkan kepada anak-anak jika tidak diajarkan atau jika tidak diimbangi dengan bahasa Indonesia, mungkin anak-anak akan menggunakan bahasa Indonesia apabila berada di sekolah, jika dirumah atau sedang bermain barulah menggunakan bahasa Jawa.

Peran aktif orang tua sangat diperlukan dalam hal ini, dengan kata lain orang tua pun dituntut untuk mengetahui sedikit tentang bahasa Inggris agar mereka bisa membeli buku tentang dasar bahasa Inggris dan mengajarkannya pada anak-anak mereka di rumah. Pengasuhan orang tua yang diberikan pada anaknya bukanlah pengasuhan yang sifatnya sementara dan singkat, akan tetapi pengasuhan yang sifatnya interaksi antara orang tua dan anak secara langsung, dalam mengasuh orang tua bukanlah hanya mampu mengkomunikasikan fakta, gagasan dan pengetahuannya saja, melainkan langsung membantu menumbuh kembangkan anak secara maksimal. Dalam pelaksanaan pengasuhan seyogyanya orang tua tidak memaksakan kehendaknya, tetapi harus mengetahui apa yang dibutuhkan anak dan sesuai dengan usia perkembangan anak. Semua itu dimengerti oleh orang tua bila mereka mengerti dan peduli terhadap proses pengasuhan anak dalam keluarga. Kepedulian orang tua terhadap pengasuhan selain didasari faktor alami juga karena faktor latar belakang pendidikannya, peranan pendidikan masing-masing orang tua sangatlah berpengaruh pada pemberian pengasuhan. Anak akan menjadi tumbuh dan berkarakter karena peranan pengasuhan orang tua yang mendasarinya. Perbedaan pendidikan yang dimiliki orang tua akan dapat terlihat pada kualitas hasil proses pengasuhan.

Sehingga menurut peneliti ketika terjun langsung ke lapangan banyak orang tua yang menyampaikan bahwa kebanyakan orang tua memang mengajarkan bahasa lain atau bahasa kedua di rumah. Menurut teori yang adapun orang tua memang harus berkomunikasi dengan baik saat berada di rumah agar anak bisa menggunakan dan agar anak terbiasa dengan bahasa Inggris sehingga anak tidak kaku atau merasa bahwa belajar bahasa Inggris hanya di sekolah saja.

Pemahaman orangtua tentang bahasa Inggris. Sejauh ini hanya beberapa orangtua yang mengerti bahasa Inggris, sebagian lagi kurang memahami bahasa Inggris. Dari delapan informan ada dua orangtua yang mengerti tentang bahasa Inggris sedangkan lima orangtua lainnya kurang begitu memahami dengan Bahasa Inggris. Karena menurut mereka, sudah terlambat untuk kembali belajar bahasa Inggris sehingga tidak perlu lagi belajar hanya saja mereka tidak ingin semua itu terjadi lagi pada anakanak mereka, jadi mereka ingin pendidikan terbaik untuk anak-anak mereka. Dan satu orang tua lagi yang benar-benar tidak mengerti dengan bahasa Inggris karena menurut informan, latar belakang pendidikan terakhirnyalah yang membuatnya buta sekali dengan bahasa Inggris. Beliau juga banyak mengeluh saat anak bertanya pada kedua orang tua nya saat berada di rumah, mereka berdua benarbenar tidak mengerti dengan bahasa Inggris, mereka berdua hanya bisa 
mengalihkan kegiatan, misalnya mengganti mainan yang mengacu pada pertanyaan soal bahasa Inggris yang si anak tanyakan pada mereka.

Mengutip salah satu hadis dalam agama Islam: "Belajarkanlah anak-anakmu karena mereka adalah makhluk ciptaan Tuhan yang akan memasuki zaman yang berbeda dengan keadaan zamanmu sekarang". Menurut (Sudjana, 2000, p.68) para pendidik termasuk orang tua (bapak dan ibu) dituntut kemampuannya untuk memantau dan memprediksi kecenderungan perubahan di masa depan serta untuk merencanakan dan menerapkan program kegiatan belajar yang lebih mendekati/cocok dengan tuntutan kehidupan masa depan. Orang tua sebagai pendidik anak dalam keluarga adalah yang paling bertanggung jawab terhadap pertumbuhan dan perkembangan anak.

Disinilah peneliti menemukan pendapat orang tua dan teori bisa disejajarkan bahwa memang seharusnya orang tua memiliki pemahaman yang baik dalam bahasa Inggris agar anak-anak bisa dapat mengerti dengan baik apabila anak sedang berada dirumah. Komunikasi haruslah berjalan baik antara orang tua dan anak sehingga perkembangan anak bisa tercapai sesuai pertumbuhan dan perkembangan anak. Menurut teori pun orang tua memang dituntut untuk memiliki kemampuan dalam segala hal termasuk salah satunya bisa memahami bahasa Inggris, karena orang tua adalah guru pertama anak-anak. Bagaimanapun juga anak-anak pasti akan lebih banyak bertanya kepada orang tua dibandingkan guru, karena memang waktu berada dirumah lebih banyak dibandingkan anak-anak berada di sekolah.

Persepsi Guru Mengenai Bahasa Inggris Pada Anak Usia Dini

Latar belakang pendidik tenaga pengajar di TK, kebanyakan tenaga pengajar di TK ABA Karangmalang mempunyai pendidikan terakhir Strata 1, namun kebanyakan dari mereka memang tidaklah lulusan S1 PAUD, namun ada bermacammacam lulusan: S1 BK, S1 Sejarah, dan lain-lain.

Guru adalah orang yang sangat berpengaruh dalam proses belajar mengajar. Oleh karena itu, guru harus betul-betul membawa siswanya kepada tujuan yang ingin dicapai. Guru harus mampu mempengaruhi siswanya. Guru harus berpandangan luas dan kriteria bagi seorang guru ialah harus memiliki kewibawaan (Cece, Djaja \& A. Tabrani, 1992, p.62). Kewibawaan adalah sesuatu yang sangat penting untuk dimiliki oleh seorang guru. Guru yang mempunyai kewibawaan berarti mempunyai kesungguhan, suatu kekuatan, sesuatu yang dapat memberikan kesan dan pengaruh. Menurut (Jayne Moon, 2000, p.210) pembelajaran bahasa Inggris bagi anak usia dini adalah suatu bidang yang dinamis sehingga bisa dipastikan akan senantiasa mengalami perubahan-perubahan. Namun demikian tugas para pendidik bagi anak usia dini tetaplah sama yakni membantu perkembangan pemahaman dan penggunaan bahasa mereka. Melalui perencanaan, pembimbingan, dan penyediaan sarana penunjang yang memadai.

Jadi, menurut peneliti bahwa latar belakang pendidikan seorang guru sangatlah berpengaruh dalam profesinya saat ini, namun jika basic (dasarnya) adalah pendidikan, menurut saya masih bisa untuk mengajar anak-anak di TK untuk mengajar. Yang terpenting bisa mengerti bagaimana cara mengajar anak-anak sesuai dengan perkembangan anak. Menurut teori pun pendidik memilik tugas yang sama yakni membantu perkembangan pemahaman dan penggunaan bahasa mereka, melalui perencanaan, pembimbingan, dan penyediaan sarana penunjang yang memadai.

Pendapat guru mengenai bahasa Inggris untuk Anak Usia Dini, guru banyak mengerti tentang bahasa Inggris, mereka 
sudah diberi bekal banyak sebelum mengajar, sudah memiliki banyak cara aktif untuk anak-anak, cara mengenalkan bahasa Inggris dengan baik dan benar sesuai dengan pemerintah hanya sekedar pengenalan dan membahas bahasa Inggris dasar. Selain itu juga mereka sangatlah terbuka dengan pentingnya bahasa Inggris pada anak-anak zaman sekarang, sehingga mereka pun sudah menyiapkan pembelajaran yang sesuai dengan perkembangan bahasa, kognitif, moral dan lain-lain untuk peserta didik mereka. Menurut guru-guru anak-anak juga sangatlah senang dan terbuka dalam pelajaran bahasa Inggris sehingga para guru tidak terlalu sulit menghadapi anak-anak ketika pelajaran bahasa Inggris berlangsung. Anak-anak sangat senang pelajaran bahasa Inggris, karena mereka disuguhi dengan nyanyian-nyanyian yang mereka sukai, ada juga gambar-gambar kesukaan mereka misalnya mobil-mobilan, buah-buahan, sayur-sayuran, binatang dan lain-lain. Sehingga ketika pelajaran bahasa Inggris berlangsung anak-anak tidak mengalami kebosanan dan malah lebih antusias dengan apa yang akan diajarkan selanjutnya. Inilah yang membuat guruguru berpendapat sangat baik kalau bahasa Inggris diajarkan sejak dini, karena anakanak memang sedang mengalami masamasa ingin tahu yang sangat tinggi.

Berdasarkan pengalaman para guru bahasa Inggris dan menurut para ahli bahasa seperti lagu-lagu berbahasa Inggris dapat membantu para guru untuk menciptakan pembelajaran yang aktif, kreatif dan menyenangkan. Jadi, pada prinsipnya keberhasilan proses pendidikan di sekolah sebagian besar ditentukan oleh kompetensi guru, terutama kompetensi memberikan keteladanan dengan keteladanan yang baik melalui proses pembelajaran dalam jangka waktu yang lama dan direncanakan secara komprehensif, integral maka tingkah laku utama atau terpuji anak-anak atau peserta didik dapat terbentuk. Secara konsepsional, tentu saja hal ini dapat terwujud bila semua guru di sekolah betul-betul serius dalam memberikan keteladanan.

Jadi, menurut pendapat guru dan teori mengenai bahasa Inggris untuk anak usia dini sesuai karena kedua-duanya menyebutkan bahwa mereka senang sekali dengan adanya pembelajaran bahasa Inggris untuk anak usia dini ini, menurut mereka masa keemasan pada anak sangatlah baik untuk di berikan bermacammacam pengertian untuk anak-anak karena konsep penyimpanan otak mereka cepat terangsang dengan adanya stimulasi yang jika disediakan oleh orang tua dan guru. Anak-anak juga lebih cepat menerima pelajaran dan mudah memahami dibandingkan orang dewasa.

Sikap guru atau pengajar di TK dengan adanya Bahasa Inggris. Guru atau pengajar di TK ABA bersikap positif dan sangat setuju adanya Bahasa Inggris pada Anak Usia Dini. Karena menurut mereka bahasa Inggris penting sekali untuk mereka di masa sekarang dan masa depan mereka kelak. Di TK hanya mengenalkan dengan menggunakan lagu-lagu berbahasa Inggris, gambar-gambar, permainan dan lain-lain, ini salah satu bekal untuk anak-anak agar mereka tidak terlalu buta saat mereka memasuki jenjang sekolah dasar nanti. Para guru juga mengajarkan bahasa Inggris hanya dasarnya saja, tidak membebani anak-anak dengan hafalan, dan memberikan anak-anak pekerjaan rumah. Hanya saja guru sekedar mengingatkan orang tua agar kembali mengulang pelajaran yang di sekolah kerjakan agar anak-anak bisa kembali mengingat apa saja yang mereka kerjakan selama disekolah tadi. Di sekolah, perkembangan bahasa anak ini diperkuat dengan diberikannya mata pelajaran bahasa ibu dan bahasa Indonesia (bahkan disekolah - sekolah tertentu diberikan bahasa Inggris). Dengan diberikan bahasa di sekolah, para siswa diharapkan dapat menguasai dan menggunakannya sebagai alat untuk (1) berkomunikasi secara baik dengan orang 
lain; (2) mengekspresikan pikiran, perasaan, sikap, atau pendapatnya; (3) memahami isi dari setiap bahan bacaan (buku, majalah, atau referensi lain) yang dibacanya.

Menurut teori perkembangan bahasa atau komunikasi pada anak merupakan salah satu aspek dari tahapan perkembangan anak yang seharusnya tidak luput juga dari perhatian para pendidik pada umumnya dan orang tua pada khususnya. Pemerolehan bahasa oleh anak-anak merupakan prestasi manusia yang paling hebat dan menakjubkan.Oleh sebab itulah masalah ini mendapat perhatian besar. Pemerolehan bahasa telah ditelaah secara intensif sejak lama. Pada saat itu kita telah mempelajari banyak hal mengenai bagaimana anak-anak berbicara, mengerti, dan menggunakan bahasa, tetapi sangat sedikit hal yang kita ketahui mengenai proses aktual perkembangan bahasa (Yayang, 2010, p.76).

Jadi, pendapat guru yang sangat positif dan setuju mengenai bahasa Inggris pada anak usia dini dengan teori yang juga mengatakan bahwa perkembangan bahasa anak memang sejak dini seharusnya diajarkan karena pada usia dinilah masa peka dan masa perkembangan bahasanya menjadi lebih terbentuk.

\section{Penutup}

Bahasa adalah sarana yang digunakan manusia untuk berkomunikasi dan saling berinteraksi dalam kelompok masyarakatnya. Dengan media bahasa pula, manusia dapat memahami dan mengetahui gagasan yang dimiliki orang lain juga mengungkapkan konsep yang sebelumnya masih abstrak.

Bahasa Inggris harus diajarkan pada anak sejak usia dini karena dampak dari globalisasi dan bahasa Inggris juga menjadi bahasa internasional. Pembelajaran bahasa Inggris pada anak usia dini dilakukan secara bertahap dan diajarkan hanya sebatas pengetahuan atau dasar-dasarnya saja tidak secara mendalam. Pembelajaran bahasa Inggris bisa dilakukan dengan berbagai cara, misalnya dengan nyanyian ataupun permainan agar anak tidak merasa bosan dan lebih semangat dalam belajar bahasa Inggris. Peran orang tua juga sangatlah penting dalam proses pembelajaran dengan menggunakan bahasa Inggris di rumah meskipun dalam waktu yang singkat agar bahasa Inggris anak semakin berkembang.

Selain terdapat kelompok pertama yang bahasanya langsung dapat dikuasai anak, terdapat kelompok di luarnya yang mempunyai bahasa tersendiri. Hal ini terjadi karena bahasa bersifat arbitreri dan merupakan kesepakatan umum dari kelompok pemakai bahasa tersebut. Bahasa yang dimiliki kelompok kedua ini selanjutnya disebut sebagai bahasa kedua. Manusia perlu mempelajarinya jika ingin berkomunikasi dengan masyarakat pengguna bahasa kedua agar komunikasi yang ada berjalan lebih lancar.

Pembelajaran bahasa kedua (bahasa Inggris) kemudian diberikan untuk memenuhi kebutuhan ini. Dampak yang timbul karena pembelajaran bahasa kedua diberikan sejak usia kanak-kanak antara lain membuat pemerolehan bahasa pada anak-anak bertambah. LAD sebagai perangkat bahasa yang diperoleh anak sejak lahir akan menjadi lebih aktif sehingga meningkatkan pemerolehan bahasa anak. Dampak yang lain adalah pembelajaran bahasa kedua yang diberikan sejak usia dini dapat mempengaruhi kebanggaan anakanak pada bahasa Indonesia atau bahasa daerah sebagai bahasa pertama (bahasa ibu). Rasa nasionalisme dan cinta tanah air selanjutnya menjadi hal yang dipertaruhkan karena pembelajaran bahasa kedua dibersamai dengan globalisasi yang membawa arus ide, paham, dan budaya asing dengan sangat mudah.

Pembelajaran bahasa kedua (bahasa Inggris) selain membawa pengaruh positif, yaitu mampu meningkatkan pemerolehan bahasa anak, ternyata juga memberikan 
pengaruh negatif bagi perkembangan bahasa anak. Yaitu mampu melunturkan semangat nasionalisme dan sikap bangga pada bahasa dan budaya sendiri. Pembelajaran bahasa kedua juga berperan pada rendahnya kemampuan anak tentang bahasa pertama.

Hal inilah yang kemudian layak untuk diperhatikan oleh orang tua saat memutuskan untuk memberikan pembelajaran bahasa bagi anak. Perkembangan otak dan psikologi anak harus menjadi hal yang dipertimbangkan sebelum memutuskan. Guru sebagai pendidik dan pengajar juga harus tetap menanamkan pengertian tentang pentingnya bahasa pertama di atas bahasa kedua agar tetap menjaga kebanggaan pada tanah air sendiri. Sedangkan anak sebagai pebelajar harus menyadari juga bahwa bahasa kedua tidak lantas membuat mereka melupakan budaya sendiri. Anak-anak di tengah arus globalisasi harus tetap menjaga sikap nasionalisme agar tidak terombangambing dan tetap memiliki jati diri seebagai bangsa Indonesia.

Saran peneliti untuk pembaca agar lebih mengembangkan pembelajaran bahasa Inggris. Jika sejak usia dini tidak belajar bahasa Inggris dengan tepat, maka mulai saat ini diharapkan agar lebih mengembangkan bahasa Inggris. Lebih baik terlambat daripada tidak sama sekali. Sebagai pendidik harus mengajarkan bahasa Inggris sejak anak usia dini, agar mereka fasih dalam bahasa Inggris.

\section{Daftar Rujukan}

Adrian, B,. Florina, E.B. (2013). Teaching Young Learners to efficiently Communicate in English. 3, 123126.

Cece Wijaya Djadja \& Rusyan, A. Tabrani. (1992). Upaya Pembaharuan dalam Pendidikan dan Pengajaran. Bandung : Remaja Rosdakarya.
Daradjat Zakiah. (1994). Remaja, Harapan dan Tantangan. Jakarta: Ruhama.

Hasan Ozkan, (2010). International Conference on New Trends in Education and Their Implications. To Extent does English Language Teacher education Curriculun Prepare Prospective Teachers for Teaching Young Learners. 18, 978 6053641049.

Hurlock, B Elizabeth. (1978). Perkembangan Anak. Jakarta.Erlangga

Jiyono dan Noor Suparyanti. (1997). Pengembangan Peningkatan Pendidikan dan Pelatihan Wanita Untuk Meningkatkan Prestasi Belajar Anak. Jurnal Kajian Dikbud No. 009, Tahun III. Jakarta: Dikbud.

Lexy J. Moleong. (2011). Metode Penelitian Kualitatif. edisi Revisi. Bandung: Rosdakarya.

Moon, Jayne. (2000). Children Learning English. Oxford: Macmillan Publishers Limited.

Morrison, George S. (1988). Early Chilhood. Ohio: Charles E. Merril Publising Company.

Papalia, Diane., Sally Wendkos., Ruth Duskin Feldman. (2001). Human Development eight edition. New York: McGraw-Hill Book Company.

Sudjana. 2000. Pendidikan Luar Sekolah Wawasan, sejarah Perkembangan, Falsafah dan Teori Pendukung serta Asas. Bandung: Falah Production.

Suhendan, Er. (2014). International Journal Soc. Sci \& Education. Which is the Most Appropriate Strategy for Very Young Language Learners. 4, 22234934. 
Sugiyono, (2010). Metode Penelitian Kuantitatif, Kualitatif dan $R \& D$. Bandung: CV Alfabeta.

Yayang. Perkembangan Bahasa Pada Anak (online) http://yayang08.student.ipb.ac.id/ 2010/06/18/perkembanganbahasa-pada-anak.html
Diakses pada tanggal 1 Januari 2016. Pukul 11.12 WIB.

Yu-wei Chu. (2014). English Language Teaching. Teachers' Beliefs in Teaching English for Kids at a Kindergarten: a Case Study of Students from the Department of Applied English. 10, 1916-4742. 